\title{
Maqâshid Revitalization in Global Era: Istidlâl Study from Text to Context
}

\author{
Abdul Mukti Thabrani \\ (Faculty of Islamic Economics and Business, IAIN Madura, Jln. Panglegur Km. 04 \\ Pamekasan, Email: abuahlawi@yahoo.com)
}

\begin{abstract}
:
The purposes of Islamic law (maqâshid syarîah) have become principal instruments for Muslim intellectual on producing or reproducing Islamic jurisprudence, to deal with everyday life of Muslim society. The purposes of Islamic law do not only enhance Islamic jurisprudence as a tool but also a spirit. In today's globalization, maqâsshid signify itself as practical necessity of Islamic jurisprudence for responding or challenging realities: from the text to the context. This paper attempts to describe istidlâl (extracting process of Islamic jurisprudence) on answering complexities of social issues and scrutinizing the classification of maqâshid syarîah. This research found that maqâshid-based approach, that is, ingrained in the narrative of revelation, implicitly or explicitly, is needed to answer social problems. This approach could be classified as the necessary for expressing the illat (the underlying reason), explaining the wisdom and the purposes of syarîah: partially or communally, generally or specifically. This approach aims to introduce new perspectives of maqâshid syarî'ah, such as hifdz al-bi'ah (environmental preservation), hifdz al-'alm (cosmic protection), tolerance, human rights, and freedom, which are based on contextual relevance.
\end{abstract}

\section{Keywords:}

Revitalization, Maqâshid Sharia, Istidlâl, Context

\begin{abstract}
Abstrak:
Maqâshid syarîah merupakan instrumen yang sangat penting bagi seorang mujtahid untuk memproduksi hukum Islam sebagai solusi persoalan kehidupan sehari-hari. Tanpa memahami fikih maqâshid, maka ajaran Islam hanya akan terkesan sebagai piranti tanpa ruh. Maqâshid mengindikasikan urgensi pembentukan hukum Islam sebagai tantangan dan jawaban bagi era globalisasi. Karenanya penting untuk merevitalisasi peran maqâshid dalam kajian istidlâl
\end{abstract}


hukum dari teks ke konteks. Tulisan ini akan menggali istidlâl atau proses untuk menyimpulkan dalil dari teks hukum Islam (al-Quran dan al-Sunnah) untuk menjawab persoalan-persoalan kehidupan, dan mengetahui klasifikasi dan dimensi maqâshid syari ah dalam kerangka revitalisasi hukum Islam. Temuan penelitian menunjukkan bahwa, persoalan dan tantangan kehidupan yang semakin kompleks dan berkembang, mesti bisa dijawab secara eksplisit maupun implisit melalui teks atau narasi wahyu dengan pendekatan berbasis maqâshid. Ia dapat diklasifikasikan dalam cakupan kepentingan yang sangat mendesak untuk menampakkan illat, menjelaskan hikmah dan tujuan syariah, baik secara parsial ataupun komunal, baik secara umum ataupun khusus, dalam segala sendi kehidupan dalam berbagai tema dalam hukum Islam. Sehingga timbul varian baru dalam koridor maqâshid yang bertajuk hifdz al-bi'ah, hifdz al-'alam, toleransi, HAM, dan kebebasan, yang berpijak pada maslahah yang bersifat kontekstual.

\section{Kata Kunci: \\ Revitalisasi, Maqâshid Syarîaah, Istidlal, Konteks}

\section{Introduction}

In the development of Islamic scientific treasures, especially those related to the matter of jurisprudence or Islamic law, maqâshid sharia is a very important instrument for a mujtahid to produce Islamic law as a solution to the problems of daily life. Without understanding maqâshid fiqh, which later become a trend of study not only in Indonesia but also in almost all countries, then the teachings of Islam will only be impressed as a tool without spirit which implies the characteristics of rahmatan lil alamin which has become its eternal label. Maqshid indicates an important role in the formation of Islamic law. The progress of life and the progress of the times necessitates the continuity of ijtihad which is "framed" by maqâshid syarîah, amid the swift flow of science and technology in various fields. ${ }^{1}$

In general, the conversation about maqâshid sharia usually refers to general theories put forward by al-Ghazali and developed by al-Syathibi who later become famous with al-kulliyah al-khams (five

\footnotetext{
${ }^{1}$ Abdul Mukti Thabrani, "Tansiq Maqashid al-Syariyyah wa al-Manahij al-Fikriyyah," Jurnal Islam and Civilisation Renewal, IAIS Malaysia, Vol 8, No 1, 2017: 108
} 
general principles of maintaining religion, soul, reason, honor, and property). ${ }^{2}$ Urgency of maqâshid syarîah in Islamic law is vital, because it can reveal wisdom, purpose, and illah or the real reason for a law. Maqashid is the core of Islamic law (figh) itself. Knowing the maqâshid is a necessity because in principle you know maqâshid syarîah the same as understanding religion and knowing the rules of the shari'a itself. ${ }^{3}$

With the development of thinking and the free mindset of the Muslims along with global change, it is necessary to revitalize the maqâshid syarîa in answering current problems so that the light of revelation and nubuwwah still illuminates the life of the ijtihad of Muslims. Even for planning future agendas by laying the foundation or way of istinbath based on maslahah from a primary source text with the perspective of maqâshid sharia. ${ }^{4}$

\section{Inevitability of Revitalization of Maqâshid}

Revitalization of maqâshid is a necessity to frame Islamic studies as frames, and also for legal formulation as a result of ijtihad in various fields of life, so that Islamic teachings are not considered "out of date" or dead in the arena of scientific battle. In the view of alJuwaini, people who do not understand the maqâshid sharia, will not understand Islamic law. Because from the time of tâbi'în until now, Islamic scientific transformation or Islamic sharia in general has found its essence after being formulated from text to context. ${ }^{5}$ Understanding and interpretating that are correct and in tune with maqashid shari'a, is the most important element in Islamic law or ijtihad in digging Islamic law that will ultimately become the legal basis for human benefit. Because the problems of human life are explicit and some are implicit in the revelation text. Besides, there is

${ }^{2}$ Abû Hâmid al-Ghazâlî, al-Mustashfa min 'Ilm al-Ushûl, Beirut: Dâr al-Turâts al-Arabî, 1990, 322, dan Abû Ishâq al-Syâthibî, al-Muwâfaqât, Vol. 2, Beirut: Dar al-Marifah, 1997,550

${ }^{3}$ Aḥmad Hammâdî al-Ubaydî, Al-Syâthibî wa Maqâshid al-Syarî'ah, Kuwait: Mansyurat Kulliyat ad-Da'wah al-Islamiyyah wa Lajnah al-Huffadz 'ala at-Turas al-Islami, 1992, 99.

4 Khâlid Dâkhil, al-Wa'y al-Muntadzar fí al-Islâm, Jurnal al-Ma'rifah, No 82/2002, Wizarah Ma`arif, Riyadh, KSA

${ }^{5}$ Al-Haramayn al-Juwaynî, al-Burhân fî̀ Ushûl al-Ahkâm, Kairo: Dar al-Wafa, tt, 295 
the shift in values and social development that always follows the development of the art of life in the world. ${ }^{6}$

The importance of revitalizing maqâshid in various studies and explorations of Islamic law, finds its relevance when the current reality of Muslims is faced to many problems which later become fields of cultivation for scholars who were experts in the field of maqâshid sharia. This domain is very broad and challenging according to the breadth of the field of human life in the world. Borrowing the term used by Ibn 'Âsyûr, a very brilliant maqâshid expert, Muslims in the future must have "ahlâm syariah" or sharia dreams that will make him lead the field of life. This dream of the future is certainly not just a figment if implemented and well planned. And one very good first step is to revitalize the maqâshid fiqh in exploring the text of revelation and presenting it in the context of life in accordance with the intention of the giver of revelation. This is the main goal of the maqâshid sharia. Amid some of the people who still follow the "logic of the" centuries past were very anti-progress, it does not hurt to make maqashid the basic foundation for the progress of Islamic scholarship beginning with istidlâl text from primary sources apocalyptic in Islam, headed grounded context. ${ }^{7}$

There are a number of things that have become the starting points for the importance of maqâshid revitalization in the context of present life. Among other things, a paradigm shift in reference to Islamic law from individuals to groups. Kulliyat khamsah offered by alSyâtibî was time to be developed after so long being the core axis of the maqâshid sharia for centuries. Development towards a wider and adaptive axis of civilization. So that the next node is the system and unity, and not individuals who have completed the task of their time. At this point, the maqâshid will become a kind of renewal and liberation movement for a machine of life that is called a sustainable Muslim civilization.

\footnotetext{
${ }^{6}$ Ainul Yakin, Urgensi teori maqashid dalam penetapan hukum Islam, Jurnal at-Turas, Vol. 2 No. 1 Juni 2015: 27

${ }^{7}$ Muhammad Thâhir Ibn `Âsyûr, Maqâshid al-Syarî‘ah al-Islâmiyyah wa Makârimuha, Beirut : Dar al-Shafa, 1986, 87
} 
Next is the importance of the discoloration of the unfinished "verb" maqâshid from the era of al-Juwaynî, al-Ghazâlî, and al-Syâthibî, towards a new era that beautifies the kulliyat khamsah icon from simply "keeping the five main things" to "renew" and "expand" or "create" new problems for life. As already pioneered by Ibn "Âsyûr by developing basic things in a broader direction, namely tolerance, human rights, and freedom .8And what Ibn Taimiyah did with the terminology of tahshîl, the reason for wa takmîliha (seeking and perfecting maslahat) and ta'thîl mafâsid wa taqlîliha (reducing and preventing damage). ${ }^{9}$ As the development of "nasab" which later developes into citizens, family, society, and universal humanity. And most recently, the combination of these basic things with the theory of pyramid of basic human needs developed by Abraham Maslow, which is very close to the theory Ibn Taymiyah and Ibn Assyria. ${ }^{10}$

In addition, another thing that has encouraged the need for revitalization is the expansion of the object of the study of maqâshid sharia in various fields, not only limited in the field of jurisprudence or Islamic law. Because Allah as musyarri ' also does not limit religion only in matters of principle, but also in terms of juz'iyyah or parsial as a complementary element and perfecting religion or the rules of Islamic law. In other words, the parts of religion must be linked to the maqshid or its purpose. This makes it possible to bring forth new sciences as variants or derivations from the main fiqh, such as fiqh muwâzanah, and others needed by the times, as a fruit of the understanding of the maqâshid extracted from the source. And the most important thing is to stem the radical and narrow understanding that undermines religion in the midst of the global era. ${ }^{11}$ Because the main purpose of this religion, as stated in the main norm is dar' al-mafâsid wa jalb al-mashâlih (avert danger and pick benefit).

\footnotetext{
${ }^{8}$ Ibid., 80

${ }^{9}$ Ahmad Ibn Taimiyah al-Harrani, Majmû' Fatawa, Beirut: Dar al-Wafa', tt, Vol 5, 187

${ }^{10}$ Jamaluddin Atiyyah, Nahwa fa'aliyyat al-maqashid al-syariah, Kairo : Dar al-muasir, 1990, 45

${ }^{11}$ Syamsuddin Arif, Epistemologi Islam, Jurnal Islamia, Tahun II, No. 6, 2006, Jakarta: Insist.
} 


\section{The Maqâshid Theory in the Flow of Islamic Law}

In Ibn Taymiyyah's perspective, the revitalization of maqâshid is very important because the terminology of maqâshid is a verb that is never finished. According to him, safeguarding the five basic things in the maqâshid principle known as al-kulliyyah al-khams needs to be revitalized to become improvements, utilization, and expansion of benefit in general.12 Because, the main purpose (maqâshid) of sharia is the creation of benefit or public interest in human life, both worldly and ukhrawi, which is dynamic and flexible, developing along with the development of time, place, and condition. Consequently, it can do something that is considered useful at a time is not necessarily considered to be a benefit at another time. In addition, something that is considered beneficial in a certain place is not necessarily considered to be a benefit in another place. ${ }^{13}$

Based on this mass estuary, the revitalization of maqâshid in the application of Islamic law by considering aspects of benefit or public interest needs to be encouraged. This instrument is a way for shari'a laws to accommodate every development that exists, so that Islamic law can be accepted at any time and place.

In order to maintain the harmony of Islamic sharia teachings with the development of social life, then in contemporary times there is a great need for revitalization and also various renewal efforts. To guard Islamic law remains dynamic, responsive, and has high adaptability to the demands of change, needs to revive and excite ijtihâd among Muslims. The problem then is that the number of verses of the Koran and hadith that talk about legal matters is very limited. While social development raises a variety of new features in people's lives. With these two facts, Muslims are faced with a challenge; are they able to prove the truth and principle that Islam can always be accepted anytime and anywhere. ${ }^{14}$

So facing this condition, a variety of Islamic fiqh renewal ideas emerged among contemporary Muslim intellectuals. Rests on two basic fundamentals, namely the revelation and fenomena social. One

\footnotetext{
${ }^{12}$ Ibn Taimiyyah, Majmû́ Fatawa, Vol. 2, 43

13 Ibid., 211

${ }^{14}$ Jamal D. Rahman, Wacana Baru fiqih Sosial, Jakarta: Khazanah ilmu-ilmu Islam, 1977, 147
} 
of the reforms that is widely discussed is the methodological approach in ijtihad by using the maqâshid sharia as its instrument. In the midst of sacred situation and limited texts, maqâshid sharia approach that leads to benefit considered as an approach that is able to answer the challenges of the times with all aspects of social change. However, efforts to use the maqâshid approach must pay attention to the criteria of mashlahah that have been mentioned. Even though the existence of ijtihâd is a sharia instrument against a condition that requires solutions and solutions. ${ }^{15}$ In this context two conditions arise, namely conditions that require and conditions that do not require ijtihad. The majority of scholars argue that it is obligatory to carry out jihad in the first condition. ${ }^{16}$ Every condition that gave birth to ijtihad in its various spectrums must be colored by various things outside of revelation, such as politics, social, culture and economy. From here, the dynamics of ijtihad to revitalize maqshid in the study of Islamic law found its relevance in synergy with time. ${ }^{17}$

The maqâshid sharia perspective is the main prerequisite in understanding Islamic law and has an important role in mapping legal texts (nushûs syar'iyyah) so that it can give birth to independent mujtahids in every era. This perspective is widely used by scholars, including hadith scholars such as al-Tirmidzi, who aggressively discussed the maqâshid prayer in one of his books. AsSyafiiyah scholars who are good at using this perspective, are alQaffal, al-Juwa, al-Razi, al-Amidi, al-Baidlawi, al-Subki, and Izzuddin Ibn 'Abd al-Salam. In which it is then denied by al-Syâthibî by making the maqshid a separate discipline. ${ }^{18}$

While Yusuf al-Qardlawi, with his theory of figh awlawiyât or priority jurisprudence, said that there must be a priority scale in the determination of law through the door of ijtihâd, including the term of maqûshid from text to context. Which one is an emergency, needs or

\footnotetext{
${ }^{15}$ Abdul Mukti Thabrani, Mazhab Fikih dan Kedaulatan Umat, Jurnal Karsa, 2007

${ }^{16}$ Lihat al-Ghazali, al-Mustashfa min 'Ilm al-Ushûl, Cet 1, Dar ihya' al-turats: Beirut, 1997, 170. Wahbah al-Zuhaylî, Ushûl al-figh al-Islâmî, Cet 1, Dar al-fikr: Beirut, Vol 2, 1986, 1052.

${ }^{17}$ M. Quraish Shihab, Membumikan al-Quran 2, Lentera Hati: Jakarta, 2010, 466.

18 Ahmad al-Raysunî, Nadzariyyat al-Maqashid inda al-Syatibi, Beirut: Dar al-Salam, 1990, 216
} 
desires, in which in fiqh language we are familiar with the terms of dlarûriyyât, hajiyyât, tahsîniyyat. According to him, priority jurisprudence must be seen as a knife of analysis in various purposes of the (legal) approach. ${ }^{19}$

\section{Dimensions Maqâshid and Its Context}

Maqâshid Syarîa'h is classified in various ways, based on a number of dimensions and perspectives. ${ }^{20}$ Judging from the dimensions of generality or generalization and its specificity or specifications, maqâshid sharia is divided into three, namely general maqâshid (al-maqâshid al-'ammah) which covers all legal aspects whose purpose is to benefit and reject damage in the world at once in the hereafter. This maqâshid is not related to the legal details of the discussion of Islamic law. ${ }^{21}$

The second is the special maqâshid (al-maqâshid alkhasshah) namely maqâshid which can be observed throughout the contents of certain Islamic law chapters, such as family welfare and the sustainability of regeneration which are the goals of being married (munâkahah), protection from crime in criminal law (jinâyah), and protection from monopoly in economic law (mu'âmalah).22 While the third is partial maqâshid (al-maqâshid al-juz'iyyah) which are the goals behind a certain text or law, such as revealing the truth on the provisions of the number of certain witnesses in certain legal cases, easing the difficulty of allowing sick people not to fast, feeding poor

\footnotetext{
${ }_{19}$ Yusuf al-Qardhawi, Figh Prioritas: Sebuah Kajian Baru berdasarkan al-Quran dan alSunnah, Robbani press: Jakarta, 2012, 12.

${ }^{20}$ Ibid., 37.

21 al-Syâthibî, al-Muwafaqat fi Ushul as-Syari'ah, Vol. 2, Beirut: Dar al-Kutub al'ilmiyah, 2005, 7

22 al-Syatibi full name Ibrahim ibn musa bin Muhammad, with his nickname Abu Ishak descended from Banu Lakhm. The family of Imam Syatibi is of Arab-Yemeni descent from Banu Lakhm from Bethlehem, Ash-Sham. The name As-Syatibi itself is related to an area east of Andalus named Syatibah or Sativa which is the origin of Imam Syatibi's parents. This area is quite famous at the end of the glory of Islam in Spain. Many other well-known ulama scholars were born from this area. Al-Syatibi was born in $720 \mathrm{H}$ and died in $790 \mathrm{H}$. He was known as Mr. Maqashid Syariah because he was the first to compile the book Maqashid systematically and comprehensively through the munomental work of al-Muwafaqat fi Ushul asSyariah.
} 
people and prohibiting Muslims from hoarding meat during ' $\hat{I} d$ alAdlha. ${ }^{23}$

Whereas if viewed from the dimension of certainty, then the maqâshid sharia is divided into three. Namely the maqâshid qath'iyyah or sharia destination or Islamic law which is directly explained by the text of the text which does not contain the possibility of being devised or misused for certain purposes. Like the purpose of marriage is the creation of a sakinah family, or peace, which is directly explained by nash al-Qur'an. The purpose of prayer is to abstain from abomination and munkar (tanha 'an al-fahsya' wa almunkar). The second is maqâshid dzanniyyah or the goal of sharia which is explained by texts that are uncertain (dzanni) and or which are considered by reason (through the process of ijtihad) there is great benefit, such as recording in a wedding and others. There is also what is called the maqâshid wahmiyah or pseudo-benefit. This maqâshid is not based on a strong proposition (mu'tabar).

There is also the maqâshid which is formulated in its range of dimensions, which is then classified into two, namely the maqâshid kulliyah or the aims of sharia or Islamic law which benefit back to the human race as a whole, such as unity, cleanliness, greening, and so on. And the second, maqâshid juz'iyyah or sharia goals that return to each individual or group of people, such as the goals contained in muamalat.

In addition to these classifications there are also scholars who make categories based on their needs, then what comes to be known as the maqâshid dlaruriyah or the level of need that must exist or is called the primary need. If the level of this need is not met, the safety of humanity will be threatened both in the world and in the hereafter. ${ }^{24}$ According to al-Syathibi ${ }^{25}$ there are five things that fall into this category, namely maintaining religion (hifdz aldîn), nurturing the soul (hifdz al-nafs), nurturing reason (hifdz al-'aql), preserving honor and descent (hifdz al-nasl), and maintaining property(hifdz al-mâl). To maintain these five points, Islamic Sharia is

\footnotetext{
${ }^{23}$ Ibid., 8.

${ }^{24}$ Ahmad Sahal dkk, Islam Nusantara: Dari Ushul Figh Hingga Paham Kebangsaan, cet. Ke III, Mizan, Jakarta, 2016, 104

${ }^{25}$ al-Syâtibî, al-Muwafaqat..., 9
} 
revealed. Every legal verse if examined will be found the reason for its formation which is none other than to maintain the five points above. ${ }^{26}$

These five principles are known as al-kulliyyat al-khams (five universal principles) or al-dlaruriyyat al-khams (five principles of necessity or primary or primary needs). Al-Syatibi stated that these five principles were consensus of religions (ittifaq al-milal). Or in other other words, the general values of religions. While Abdullah Darraz said that these five principles are the foundations of the development or progress of society in all religions, where without these five bases, human life together will not be stable and happiness in the hereafter will not be achieved. ${ }^{27}$ Whereas the maqâshid hajiyyah are basic needs that are secondary in nature, where if it is not achieved or not fulfilled, it does not threaten safety, but people will experience difficulties (masyaqqah). There is a rukhshah (lightening) law, for example, Islamic sharia concerns for this benefit. ${ }^{28}$

In the field of worship, Islam prescribes several laws of rukhshah (lightening) if in reality it is difficult to carry out taklif commands. For example, Islam allows not to fast if on a trip within a certain distance with conditions replaced on another day and so does the person who is sick. The ability to perform qasar prayer is in order to fulfill the needs of this pilgrimage. In the field of $m u^{\prime}$ amalat there are many types of contracts (contracts), as well as various types of buying and selling, leasing, syirkah (company) and mudlarabah (trading with other people's capital with profit sharing agreements) and some rukhshah laws in mu'amalat. In the field of 'uqubat (legal sanctions), Islam mandates the diyat (fine) sentence for accidental murder, and suspends the hand cut sentence for someone who stole because it was pressed to save his life from starvation. ${ }^{29}$

Maqâshid tahsiniyah is a level of need which if not fulfilled does not threaten the existence of one of the five points above and does not cause difficulties. The level of this need is in the form of

\footnotetext{
${ }^{26}$ Ibid., 9

${ }^{27}$ Ibid., 9

${ }^{28}$ Ibid., 7

${ }^{29}$ Ibid., 4
} 
complementary needs, as stated by al-Syathibi, things which are propriety according to customs, avoiding things that are not pleasing to the eye, and decorated with beauty in accordance with moral and moral demands. ${ }^{30}$ This maqâshid tahsiniyah covers in various fields of life, such as worship, mu'âmalah, and 'uqûbât. In the field of worship, Islam implies purification either from unclean or hadas, both at the body and at the place and environment. Islam recommends decorating when going to the mosque, advocating, multiplying the sunnah worship. In the field of $m u^{\prime}$ amalat Islam prohibits wasteful, miserly, raising prices, monopoly, and others.

In addition to the above classification, broadly speaking, or globally, the maqâshid is divided into two, ${ }^{31}$ namely maqâshid alSyâri which contains four aspects, the initial purpose of Syâri' (Allah and His apostles) establishes sharia which is for human welfare in the world and the hereafter. So in this case, the establishment of sharia as something that must be understood and also as a law taklifi that must be implemented. In addition to the establishment of shari'ah in order to bring humans under the protection of the law that is to avoid following the passions. ${ }^{32}$ Then the second is maqâshid al-mukallaf which contains aspects of mashlahah and taklif or the burden of human obligation to do daily activities starting from worship, mu âmalah, and other activities.

\section{Dimensions of Development and Contextualization}

Almost all contemporary usul ulul figh scholars, including Ibn 'Asyur, agree that Imam as-Syatibi is the one who pioneered the emergence of the science of Maqâshid Syariah through his munomental al-Muwafaqat work. So it would not be an exaggeration if he was referred to as MrMaqshid and at the same time the foundation. However, it does not mean that before he, there is no knowledge of Islamic maqâshid. Al-Syâthibî is more appropriately called the first person to compile it systematically. As Shafi'i is known as the basic layer of the science of ushûl al-figh systematically.

\footnotetext{
30 Sri Lu'matus Sa'adah, Peta Pemikiran Figh Progresif, Pustaka Pelajar: Yogyakarta, 2012, 43

${ }^{31}$ Jasser Auda, Membumikan Hukum Islam melalui Maqashid Syariah: pendekatan teori dan sistem, terj Rasidin Ali dan Abdul Munim, Mizan: Bandung, 2008, 31

32 Ibid., 41
} 
At the time of the Prophet and the Companions, the idea of the maqâshid syarîah or the aims or intentions underlying the commandments of the Qur'an and the Sunnah can be traced to the time of the companions of the Prophet Muhammad as narrated in a number of events. One of the most popular examples is the mutawâtir hadith about the ashar prayer in Banu Quraizhah, where the Messenger of Allāh sent a group of friends to the Banī Quraizhah for certain purposes, and ordered them to carry out the asr prayer there. But what happened, the time limit for Asr prayers was almost gone and the friends arrived at Banu Quraizhah. Then the friends were divided into supporters of two different opinions: the first opinion insisted on the Asr prayer in Banu Quraizhah with any consequence that occurred, while the second opinion insisted on the Asr prayer on the journey (before the time of Asr prayer finished). ${ }^{33}$

The rationalization behind the first opinion is that the order of the Prophet Muhammad textually asked everyone to carry out the Asr prayer in Banu Quraizhah, while the rationalization of the second opinion was focused on the 'intention' of the Prophet Muhammad asking friends to rush to Banu Quraizhah and not 'intend ' to postpone the prayer of Asr until the time of prayer. According to narrators, when the Companions reported the story to the Prophet, He confirmed the truth of the two opinions of the Companions. Takrîr Rasulullah as the fâqih and ulama, shows the ability and the second truth in the above view. ${ }^{34}$

Another example that shows the more serious consequences of applying the maqâshid sharia -based approach to the Prophet's order occurred at the time of Umar ibn al-Khattab, 35 where in that event the Companions of the Prophet SAW asked the Caliph Umar to distribute the lands which the Muslims had conquered in Egypt and Iraq to them as a part of the spoils of war (ghanimah). Their argument is based on the verses of the Qur'an which clearly allow the soldiers (mujâhid) to obtain ghanimah, but Umar refused to divide the entire land and the spoils of war to the companions, the purpose of Umar is that wealth is

\footnotetext{
${ }^{33}$ Ibid., 42

${ }^{34}$ Abdul Mukti Thabrani, “Tata Kelola Negara Madinah pada Masa Nabi SAW," Jurnal In Right, UIN sunan Kalijaga, Vol. 4 No 1, 2014

${ }^{35}$ Ibid., 43
} 
not dominated by the rich people. ${ }^{36}$ Caliph Umar prefers to put forward the maqâshid approach by surrendering these assets to bayt al-mâl.

Another example is the decision of the Caliph Umar ibn alKhattab to include horses in the category of wealth which is obliged to be zakat, even though there are hadiths or sayings of the Prophet that exclude horses as wealth, but as vehicles. The rationalization of the Caliph Umar departed from an understanding of the maqashid, that the horse in the time of the Caliphate had significantly exceeded the value of the camel which the Prophet SAW included in the obligatory object of zakah during his lifetime. In other words, or with other arguments, the Caliph Umar understood the "purpose" of zakah in relation to the form of social assistance that must be paid by the rich for the benefit of the poor, regardless of the type of raw wealth mentioned in the Sunnah. In other words, in this case the Caliph Umar used the maqâshid approach in understanding the Prophet's Sunnah.

The above example illustrates the expression of the early history of the concepts maqâshid syarîah in the application of Islamic law and the implications that arise from giving fundamental position on maqâshid has existed since the time of the Prophet and the Friends. This period is also known as phase maqâshid introduction of sharia contained in the Qur'an and the Sunnah in the form of frozen signals that have not been melted. In other words, the maqâshid syarîah at this time is only in the form of implicit views and has not been theorized. ${ }^{37}$

After the Prophet and his companions, it could be categorized as the period of the salaf scholars. ${ }^{38}$ which at that time the theory and classification of maqâshid began to develop. But the maqâshid as we know it that time did not develop clearly and systematically until the time of the ushul fiqh experts who emerged later, namely in the 5-8 century $\mathrm{H}$. Within three centuries beginning, the idea of maqâshid,including also about wisdom, illat, munâsabah, and the meaning of looked at several methods of reasoning used by the priests

\footnotetext{
${ }^{36}$ Sri Lu'matus Sa'adah, ...42

${ }^{37}$ Jasser Auda, Membumikan Hukum Islam ...,50

${ }^{38}$ Look Ibn Qayyim al-Jauziyyah, I'lam al-Muwaqqi în, Vol. III, 54
} 
of the traditional schools, such as reasoning through qiyâs, istihsân, and the consideration of the benefit. At that time, maqâshid had not been the subject or theme (topic) of its own scientific work or of special concern, until the end of the 3rd century H.

Among the scholars who became known as pioneers in the maqâshid field, one of them was imam al-Tirmidzi (d. 296 AH/908 AD) who wrote the first famous work on the topic maqâshid, where the terminology maqâshid used as the title of the bookalshalah wa Maqâshiduha (Prayer and Purpose). This book contains a collection of wisdom and spiritual secrets behind every prayer movement with sufistic tendencies. Then comes Abu Zaid al-Balkhi (d. $322 \mathrm{H} \mathrm{/} \mathrm{933M)} \mathrm{who} \mathrm{presents} \mathrm{the} \mathrm{first} \mathrm{famous} \mathrm{work} \mathrm{about}$ the maqâshid in the field of muamalah, with his book, al-Ibanatu 'an Ilal ad-Diyanah (explanation of the objectives behind practices worship). He also wrote specifically about the benefit entitled Mashâlih al-Abdan wa al-Anfu (the Benefits of Body and Soul), he explains how the practice of Islamic law contributes to the health, both physically and mentally. In the next century appears al-Qaffal alKabir (d. 365 AH / 975 AD) he wrote the most ancient manuscripts, Mahâsin al-Syarîah (the beauty of the law of sharia). He briefly mentions each law and elaborates on maqâshid and the wisdom behind it. Then came Ibn Bubawaih al-Qummi (d. 381/991 AD), one of the fiqh scholars with Shi'a scholars who wrote books about the maqâshid subject. This book entitled 'Ilal al-syarâ' $i$ ' (reasons behind sharia law) provides a rationalization of faith in Allah, prophethood, prayer, fasting, hajj, zakat, and other obligations.

In later periods, namely the period of the Khalaf scholars there is a significant development of maqâshid as a dimension for meaning and contextualization. The literal method that developed during the salaf scholar up to the 5 th century $\mathrm{H}$ proved unable to overcome the complexity of the development of civilization. This reasoning which led to the maqâshid approach inevitably had to be developed as a method that included things that were explicitly not 
mentioned by nash, to cover up the shortcomings of the qiyâs method. ${ }^{39}$

Maqâshid approach has helped fill the gaps and encourage the birth of maqâshid theories in Islamic law. There are some scholars in this period that gave the most significant contribution to the development of maqâshid up to the 8th century AH was Abu al-Ma'ali al-Juwayni (d. 478 AH/1085 AD) with his work entitled al-Burhân fi Ushîl al-Figh (written or arguments in the Jurisprudence). This book is the treatise of the first Jurisprudence which introduces the theory of the "degree of necessity", or "level of necessity" in a manner similar to the degree of necessity of the current famelier. Al-Juwayni suggests five levels of maqâshid, namely necessity (dlarûrât), public needs (alhâjah al-'ammah), moral behavior (al-makrûmât), recommendations (almandûbât), and comprehension or protection(al-'ismah). Some reconstruction of Islamic law at al-Juwaini of which is the ease in law thahârah, removing the burden of the poor in charity law, consensual in trade law.

In the following period, came Abu Hamid al-Ghazali (d. 505 H/1111 AD) who was one of al-Juwaini's best students. Al-Ghazali further developed his teacher's theory in his book, alMustashfa (purified resources). He listed the "needs" suggested by alJuwaini as faith; soul; sense; offspring; Treasure. Al-Ghazali suggested a sequence based on the order of needs. In other words, indirectly alGhazali shows that needs at a higher level must get priority from lower needs. But on a note, these needs have conflicting implications in practical cases. Subsequently al-'Izz Ibn 'Abd al-Salam (d. 660 H/1209 AD) wrote two books about maqâshid in the nuances of wisdom that lie behind Islamic law. That maqâshid alshalâh (shalâh goals) and maqâshid al-shawm (fasting purposes). Ibn alQayyim summarizes the methodology of legal determination based on the wisdom and welfare of humans with strict sentences:

"Sharia is based on wisdom to achieve human salvation in the world or in the Hereafter. Sharia is entirely related to justice, love, wisdom, and kindness. So any law that replaces justice with injustice, love with the opposite, general benefit with evil, or wisdom with nonsense, then the

\footnotetext{
${ }^{39}$ Abdul Mukti Thabrani, Figh al-Mashaib wa al-Balaya, Jurnal al-Ihkam, vol 10, no 2, 2015
} 
law is not part of sharia, even though it is claimed to be part of sharia according to several interpretations ".40

In the next phase, the theories about maqshid were later matured by Abu Ishaq al-Syatibi (d. 790 H / 1388 AD) who wrote his great book namely al-Muwâfaqât fi Ushûl al-Syarî'ah (Conformity or harmony in the basis of sharia basis). In this book al-Syathibi developed the theory maqâshid in three substantial ways, namely by making al-mashlahah al-mursalah be part of the foundations of Islamic law. Then aiming at the wisdom behind the law becomes the basis of the law based on the foundation and the generality of maqshid. And on the emphasis on uncertainty (zanniyah) towards certainty (qath'iyah). Kitab al-Syathibi had become standard maqashid syari ah among scholars until the 20th century AD and become a major reference in the field to this day.

In the present, or contemporary period, there are several scholars who are important contributors in the maqshid field. Among them is Jasser Audah ${ }^{41}$ who are contemporary Muslim scholars who developed traditional maqâshid terminology in contemporary language, although on the other hand there were some rejections to the idea of "contemporaryizing" the term maqshid . ${ }^{42}$

One example of this contemporary idea is developing the theory of "descent protection" (hifdz al-nasl) into a family-oriented theory. Ibn 'Asyur for example, made caring for the family as the maqshid in Islamic law. In monografinya, Ushûl al-Nidzâm al'Ijtimâ' $\hat{\imath}$ fi al-Islâm (basic social system in Islam), Ibn' Ashur elaborate maqashid family-oriented and values mora 1 in Islamic law. The same case is the case with the theory of hifdz al-'aql (Protection of reason) which until recently is still limited to the intention of prohibiting drinking alcohol in Islam, now developed by including "scientific thought development", "The journey of learning", "against taklid mentalities", "preventing the flow of energy experts abroad ", and so on. ${ }^{43}$

\footnotetext{
${ }^{40}$ Ibid., 56-57

${ }^{41}$ Amin Abdullah in Jasser Auda, Membumikan Hukum Islam..., 9

${ }^{42}$ Ibid., 10

${ }^{43}$ Ahkmad Sahal, 106-107
} 
Ibn 'Asyur's contribution is a reinterpretation of the theory of hifdz al-nasl and hifdz al-'aql or as a substitute for the same theory but with a new form. This contribution has at least opened the door for contemporary scholars to develop the maqâshid theory in a variety of new ways. Regarding maqashid approach in the contemporary era is considered to be the most appropriate approach to address the complexity of the legal cases that are not uncovered in the text of the Qur'an and Hadith. However, this maqâshid approach cannot be immediately separated from the text.

\section{Maqâshid implementation in life}

Humans in general, or Muslims in particular, are now facing the challenges of contemporary dynamics that are very complex. ${ }^{44}$ Along with the complexity of the problem, the problems of Islamic law are also growing. This cannot be answered explicitly through existing religious texts. This response to complexity is often defensiveapologetic and counter-productive. As a result, most Muslims are increasingly confined to worrisome conditions, others are actually absorbed in chaos.

The old treasures of the jurisprudence of jurisprudence must be acknowledged to be no longer sufficient to answer complex contemporary problems due to changes in the context of space, time, culture and science. That is why reform efforts towards understanding and interpreting Islamic teachings should not be aimed at Islamic law or fiqh, but rather directed directly at the philosophy of Islamic law or ushûl al-figh which is a producer of figh laws. 45

It is on this basis that inevitably the maqshid -based approach is the right choice to overcome the problems of Islamic law whose pace of development cannot be stopped. Contemporary fiqh scholars must have the courage to carry out ijtihad with a new approach, namely an approach that is not only based on religious texts or old fiqh books, but also must consider the context and reality of life in society. ${ }^{46}$

\footnotetext{
${ }^{44}$ Ibid., 107

45 Abdullah bin Bayyah, 'Alaqah Maqâshid al-Syarî'ah bi Ushul al-Fiqh, London: AlFurqan Islamic Heritage Foundation, 2006, 45

${ }^{46}$ Ibid., 45
} 
In the view of Ahmad al-Raysuni, mujtahid who want to apply the law to understand reality (la budda lahu min an la yakûna ' ârifan khabîran bashîran bi al-wâqi' alladzî fihi yajtahidu wa fihî yuftî). That is, a mujtahid must equip himself with knowledge related to reality such as anthropology, sociology, politics, economics, and others. Without these assistive sciences, instead of giving benefit, it may be that the law applied actually causes misunderstanding in society. ${ }^{47}$ This is where the approach of the importance of maqâshid plays its role.

Maqâshid Approach has a significant role among schools of jurisprudence, particularly in formulating a new theory in the treasures of Islamic law excavation methods. Among Hanafis, the importance of maqâshid syarîahlook at the application of methodsistihsân, which is not limited to the essence of sharia mentioned by text and qiyâs. ${ }^{48}$ Among Law Schools, as shown in the Maliki school, maqâshid syarî'ah also received considerable attention. This is seen in the use of istinbâth methods which do not stop on the text of the Koran, the Hadith, ijma' and qiyâs. Among them, Maqashid obtain independent portions, namely the application of the methods of al-mashlahah al-mursalah. ${ }^{49}$ Among the Hanbali school, the sight of maqâshid is reflected in the method sadd aldharî' $a h$ (preventive). These efforts are such as the Hanafi and Maliki schools which do not provide themselves with the essence of sharia in the text, but also position the essence of sharia as a basis for establishing the law to reduce all possibilities that can lead to violations of sharia essence in the text. 50

In the view of the experts of contemporary maqâshid, Nur alKhadimi, the urgency of maqâshid that can be classified in a range of interests are strongly urged to reveal illat, explain the wisdom and purpose of sharia, either partially or communal, either generally or specifically, in all joint life in various themes in Islamic law. In addition to provide the ability of a jurist (fâqih) in exploring the law (istinbâth) based on that goal, which will help him understand the law

\footnotetext{
${ }^{47}$ Ibid., 45

${ }^{48}$ Ahsan Lihasanah, al-Figh al-Maqashidi indal al-Syathibi, Darus Salam: Kairo, 2000, 15

${ }^{49}$ Izzuddin Ibn 'Abdul-Salam al-Sulaimi, Qawaid al-Ahkam fi Mashalih al-Anam, Dar alKutub al-'ilmiyah, Bairut, 2010, 7

50 Hamka Haq (2007), al-Syatibi: Aspek Teologis Konsep Maslahah dalam Kitan alMuwafaqat, Erlangga: tk, 78
} 
and its application. The same is true for minimizing differences and debates in the realm of jurisprudence and religious fanaticism. Namely by making the science of maqâshid as a benchmark in the lawmaking process and organize a wide variety of opinions and prevent discrepancies.

In addition, there is a classification that is quite urgent, which combines the two extreme attitudes, namely the right extreme which tends to be textualist-scientific and the left extreme which tends to the essence and spirit of the text, but overrides what appears in the text itself. In this case maqâshid syarîah try to mediate, and to help a mukallaf in implementing taklif maximumly and completely. Besides, the urgency of maqâshid in the realm of Islamic law may also provide insight comprehensive about mashlahah and mafsadah which is the benchmark for legal determination. ${ }^{51}$

Basically the scholars of ushûl figh agreed that the main purpose of Islamic law is the creation of mashlahah or goodness and avoidance of mafsadah (damage) in the world and in the hereafter ( $f i$ al-dârayn). ${ }^{52}$ In other words, scholars agree that God has a purpose in every law that is imposed on mankind. ${ }^{53}$ However, the objectives of the sharia are explained in the text directly, some are not mentioned directly. For this reason, it takes the role of human reason to surpass these sharia objectives which lead to the creation of benefit. However, human reason cannot act freely in determining benefit or damage.

Therefore, the scholars provided criteria for benefit which could be used as the basis of Islamic law. One of the criteria mashlahah disclosed by as-Syâthibî is upholding the life of here for the creation of hereafter. With life, all the things that only contains the benefit of the world without the benefit of the Hereafter, or do not support the realization of the benefit of the hereafter, then it is not mashlahah the objectives of sharia. ${ }^{54}$

In addition to providing requirements or criteria, the scholars ushîl figh also provides a classification of the mashlahah. In terms of the level of its rank, mashlahah can be categorized into three

\footnotetext{
${ }^{51}$ Ibid., 81

${ }^{52}$ Asmawi, Perbandingan Ushul Fiqh, AMZAH: Jakarta, 2013, 129

${ }^{53}$ Ibid., 21

${ }^{54}$ Ibid., VIII
} 
types: al-dlarûriyat, al-hajiyat, and al-tahsîniyat. 55 The meaning of aldlarûriyat is mashlahah contained by deeds and actions that should not be done for the sake of human life here and hereafter, if it is not met it will be broken in the whole. Al-hajiyat is the mashlahah which is conceived by all human actions and actions in order to provide smoothness, ease and success for human life as a whole. Whereas what is meant by al-tahsiniyat is mashlahah which is conceived by all human actions in order to provide beauty, politeness, propriety, and glory to human life as a whole.

\section{Maqâshid Revitalization from Text to Context}

The purpose of sharia is the creation of benefit or public interest in human life, both here and hereafter. Benefit is dynamic and flexible. This means that benefit develops along with the development of time, place, and condition. Consequently, it could be something that is considered to be a benefit at a time or not, it would be considered as a benefit at another time. In addition, something that is considered beneficial in a certain place is not necessarily considered to be a benefit in another place. ${ }^{56}$

For this reason, ijtihâd against the application of Islamic law by considering aspects of benefit or public interest should continue to be encouraged. Ijtihad must not be stopped and closed tightly. Ijtihad is a way for sharia laws to accommodate every development that exists, so that Islamic law can be accepted at any time and place. In order to maintain the harmony of Islamic fiqh teachings with the development of social life, then in the contemporary era various reform efforts have emerged (tajdîd). This effort is certainly closely related to two sides which at some point present contradictions. Namely, on the one hand there are always dynamic social changes, while on the other hand Islamic Jurisprudence is considered a static and sacred teaching. ${ }^{57}$

To guard Islamic law remains dynamic, responsive, and has high adabtability to the demands of change, is by reviving and stimulating the spirit of ijtihad among Muslims. In this position,

\footnotetext{
55 Ridwan Nasir, pada pengantar buku “Sri Lum'atus Sa'adah, Peta Pemikiran Figh Progresif, Yogyakarta: Pustaka Pelajar, 2012, XV

${ }^{56}$ Jamal D. Rahman, Wacana Baru fiqih Sosial, Khazanah ilmu-ilmu Islam: Jakarta, 1977, 147

${ }^{57}$ Ibid., VIII
} 
ijtihâd is the inner dynamic for the birth of changes to safeguard the ideals of the universality of Islam as a system of teaching that shâlih $l i$ kulli zamân wa makân. 58

The problem then is that the number of the Koran and the hadith that talk about legal matters are very limited. While social development raises a variety of new features in people's lives. With these two facts, Muslims are faced with a challenge; are they able to prove the truth and principle that Islam can always be accepted anytime and anywhere. ${ }^{59}$ So facing this condition, a variety of Islamic fiqh renewal ideas emerged among contemporary Muslim intellectuals. Relying on two fundamental foundations, namely revelation and social phenomenon. One very widely discussed reform is a methodological approach in ijtihad using maqâshid syarîah as an instrument.

In the midst of sacredness and limited texts, the maqâshid syarîah approach which leads to mashlahah is considered as an approach that is able to answer the challenges of the times with all aspects of social change. However, Ijtihad that uses the maqâshid approach (al-ijtihâd al-maqâshidî) must pay attention to the criteria of mashlahah that have already been mentioned. Al-ijtihâd al-maqâshidî without limitation and scope which is clearly feared will open opportunities for everyone to issue a law arguing with the principle of maqâshid regardless of the understandings explained by nash. 60

\section{Conclusion}

From the previous explanation, it can be concluded that important things are outlines as a result of this study:

In principle, the problems and challenges of life that are increasingly complex and developing, must be answered explicitly or implicitly through existing religious texts. Maqâshid approach will be

\footnotetext{
58 Ridwan Nasir at pengantar buku Sri Lum'atus Sa'adah, Peta Pemikiran Figh Progresif, Yogyakarta: Pustaka Pelajar, 2012, "Peta Pemikiran Fiqh Progresif", XV

59 Jamal D. Rahman (1977), Wacana Baru fiqih Sosial, Khazanah ilmu-ilmu Islam, Jakarta, 147

${ }^{60}$ Sri Lum'atus Sa'adah, Peta Pemikiran Figh Progresif, Yogyakarta: Pustaka Pelajar, 2012, 107
} 
the right choice to address issues of Islamic law that the rate of development may not be terminated. Contemporary fiqh scholars must know the reality and have the courage to do ijtihad with a new approach, namely an approach that is not only based on religious texts or old fiqh books, but also must consider the context and reality of life in society.

The urgency of maqâshid can be classified in a range of interests strongly urged to reveal illat, explain the wisdom and purpose of sharia, either partially or communal, either generally or specifically, in all aspects of life in a variety of themes in Islamic law. The main objective of the sharia (law) of Islam is the creation of mashlahah or favor and elusion of mafsadah in here and hereafter. For this reason, ijtihad against the application of Islamic law by considering aspects of benefit or public interest should continue to be encouraged. To safeguard Islamic law remains dynamic, responsive, and has high adabtability to the demands of change by reviving the spirit (revitalization) of maqâshid sharia. So that new variants arise in the maqâshid corridor, entitled hifdz al-bi'ah, hifdz al-'alam, and so on, which are based on a contextual mashlahah.

\section{Bibliography}

Auda, Jasser. (2008). Buku Membumikan Hukum Islam melalui Maqâshid Syariah, Terj. Rosidin dan Ali Abd el-Mun'im, Bandung: Mizan Pustaka.

Asmawi, (2013) Perbandingan Ushul Figh, AMZAH, Jakarta

Ahmad Sahal dkk. (2016). Islam Nusantara: Dari Ushul Figh Hingga Paham Kebangsaan, Jakarta: Mizan.

Bin Bayyah, Abdullah. (2006). 'Alaqah Maqâshid al-Syarî́ah bi Ushul alFiqh, London: Al-Furqan Islamic Heritage Foundation.

Bungin, Burhan. (2009). Metodologi Penelitian Kualitatif, Jakarta: Grafindo Persada

Sulaimi, Izzuddin Ibn 'Abdul-Salam al-. (2010). Qawâ'id al-Ahkam fi Mashâlih al-Anam, Dar al-Kutub al-'ilmiyah, Bairut.

Raisuni, Ahmad al-. (2009). Madkhal ila Maqâshid al-Syariah, Dar alKalimah, Kairo.

Beirut: Dar al-Salam. 
Syathibi, Abu Ishaq al-. (2005). al-Muwafaqat fi Ushul al-Syari'ah, Beirut: Dar al-Kutub al-'Ilmiyah.

Ghazali, Abu Hamid al-. (1997). al-Mustashfa min Ilm al-Ushul, Beirut: Dar ihya' al-Turats.

Hariyanto, Erie. "GERBANG SALAM: Telaah Atas Pelaksanaanya Di Kabupaten Pamekasan." KARSA: Journal of Social and Islamic Culture 15, no. 1 (25 Maret 2012), 73.

Haq, Hamka. (2007). al-Syathibi: Aspek Teologis Konsep Maslahah dalam Kitan al-Muwafaqat, Tk: Erlangga.

Jamaluddin, Athiyyah.(1997) Nahwa Fa'aliyyat al-Maqâshid alSyar'iyyah, Kairo : Dar al-Salam.

Juwaini, Imam al-Haramain. (tt.). al-Burhan fi Ushul al-Ahkam, Kairo: Dar al-Wafa.

Khalaf, Abdul Wahab. (2010). 'Ilm Ushul al-Fiqh, Kairo: Dar al-Kutub al-Islamiyah.

Sa'adah, Sri Lu'matus. (2012). Peta Pemikiran Fiqh Progresif, Yogyakarta: Pustaka Pelajar.

Mudzhar, M. Atho. (2014). Revitalisasi Maqâshid Syariah dalam pengembangan ekonomi, jurnal Indo-Islamika, vol 4 no 1, 2014

Nawawi, Maimun. (2013). Reformasi Pemikiran Hukum Islam, Surabaya: Pena Salsabila.

Qardhawi, Muhammad Yusuf al-. (2012). Figh Prioritas, Sebuah Kajian Baru berdasarkan al-Quran dan al-Sunnah, Jakarta: Robbani Press.

Rahman, Jamal D. (1997). Wacana Baru Fikih Sosial, Jakarta: Khazanah ilmu.

Ibn Mas'ud, Muhammad Sa'ad ibn Ahmad. (1998). Maqâshid asSyariah al-Islamiyah wa 'alaqatuha bi al-Adillah as-Syar'iyyah, Riyadl: Dar al-Hijrah.

Shahi, Munim al-Ammar. (2009). al-`Aqidah al-Askariyyah al-Iraqiyyah al-Jadidah, Jurnal politik universitas al-Nahrain, Vol. 24.

Shihab, Muhammad Quraisy. (2010). Membumikan al-Quran 2, Jakarta: Lentera Hati.

Syarifuddin, Amir. (2010). Garis-garis Besar Fiqh, Jakarta: Kencana.

Ibn Taimiyah, Abdul Halim al-Harrani. (1986). Minhaj al-Sunnah alNabawiyah, Riyadl: IMSU Press.

Ibn 'Asyur, Muhammad Thahir. (1987). Maqâshid Syarî‘ah al-Islamiyah, Beirut: Dar al-Salam. 
Thabrani, Abdul Mukti. "Tansiq Maqashid al-Syariyyah wa al-Manahij al-Fikriyyah," Jurnal Islam and Civilisation Renewal, IAIS Malaysia, Vol 8, No 1, 2017: 108

Ulyani, Ali Nafi al-. (1995). Ahammiyah al-Jihad fi Nasyr al-Da'wah, Riyadl: Dar al-Thaiba.

www.afaqmostaqbal.com

Yakin, Ainul. (2015). Urgensi Maqashid dalam Penerapan Hukum Islam, Jurnal at-Turas, Vol. 2, No. 1.

Yasin, Muhammad Naim. (1994). Iftirad hawla Ghayat al-Jihad, Beirut: Dar al-Arqam.

Yusuf, Jamal al-Khalfat. (1983). al-'Askariyyah al-Islamiyyah wa Qadlatuha al-Idham, Beirut: Maktaba al-Manar.

Zuhaylî, Wahbah, al-. (1986). Ushul al-Figh al-Islami, Beirut: Dar alFikr. 